\title{
THEORETICAL ANALYSIS REHABILITATION POTENTIAL AND FEATURES CARE OF COMBATANTS
}

\author{
Volkova O. O., PhD student of the Department of Differential and Special Psychology, \\ Odessa I. I. Mechnicov national university, Odessa, Ukraine \\ ORCID ID: https://orcid.org/0000-0001-5841-5880 \\ DOI: https://doi.org/10.31435/rsglobal_conf/25012021/7359
}

\begin{abstract}
As a result of the hostilities that are now taking place in the East Ukraine, the psychological and physical trauma of the combatants is increasingly being seen. Due to the fact that the processes of their adaptation and rehabilitation are delayed in time, we can get stuck with even greater and deeper psychological traumatization of people who have undergone a very high level of stress and returned from the combat zone. In our opinion, the use of both independent types of psychological assistance and their complex combination will contribute to the neutralization of traumatic material, complete processing, further elimination of the long-term consequences of stressful influences in combatants, their adaptation to social life and the restoration of mental health.
\end{abstract}

Keywords: Rehabilitation potential, combatant, dolphin therapy, stress, psychodynamic approach, psychological trauma.

Introduction. As a result of the hostilities that are now taking place in the East of our state, the psychological and physical trauma of the combatants is increasingly being seen. Due to the fact that the processes of their adaptation and rehabilitation are delayed in time, we can get stuck with even greater and deeper psychological traumatization of people who have undergone a very high level of stress and returned from the combat zone. Questions regarding a more thorough study and improvement of methods for the rehabilitation of combatants can be attributed to a rather urgent problem of modern Ukraine.

V. Semke describes mental health as a state of dynamic balance of a person with the environment, when all the abilities inherent in his biological essence are manifested most fully and all vital subsystems function with optimal intensity. Some foreign researchers consider mental health to be the property of an individual's viability, provided by the full development and functioning of the mental apparatus. Domestic and foreign scientists were engaged in the study of personality and various aspects of psychological rehabilitation: B. Zeigarnik, M. Amosov, S. Baley, D. Elkin, V. Protopopov, V. Vernadsky, S. Freud, O. Luriia, L. Vyhotskyi, M. Bronshtein, P. Anokhin, K. Platonov, L. Burlachuk, V. Bleikher, V. Skumina, L. Bobina, S. Maksymenko. M. Korobov in his work describes the rehabilitation potential as a set of biological, psychological and sociopsychological characteristics of man, as well as socio-environmental factors that allow to some extent to realize its potential. In a set of qualitative and quantitative indicators of health, life and social status, a generalized assessment of rehabilitation potential is based on the results of a consistent study of its components [7]. The main criteria of mental health, according to ER Kalitievskaya, are: First - the absence or presence of severe forms of mental illness and borderline neuropsychiatric disorders; Secondly - the harmony of mental development and its age; Thirdly, the level of development of indicators of the state of leading social and professionally significant psychophysiological functions and personality traits, which determine the effective implementation of various professional educational and ordinary household tasks in everyday activities.

If we recall the story, on the day of his 70th birthday, Viktor Pavlovich Protopopov said: forces, with a promising future suddenly falls into the darkness of dementia or fusses in a whirlwind of delusional ideas. And do not think that the mentally ill person does not suffer from his illness. This is a misconception. The patient suffers from the horror that overwhelms him in the flow of delusions and hallucinations, as well as from the fact that at the time of enlightenment he understands what he is suffering from, and he is convinced that his disease cannot be cured. All this sometimes leads to suicide. Many patients, who seem even dull, retain exceptional tenderness and delicacy in their feelings and experiences [12].

Trauma is a fact of life. Veterans and their families deal with the painful aftermath of combat. They safer from flashbacks, nightmares, repetitive and distressing images or sensations, physical 
sensations, such as pain, sweating, feeling sick or trembling. But trauma is even closer, than you think. Children who lived with alcoholics, who deal with sexual violence at home of just had no attachment at home, all of this led to PTSD and affected all their lives. Bessel van der Kolk uses recent scientific advances to show how trauma literally reshapes both body and brain, compromising sufferers' capacities for pleasure, engagement, self-control, and trust. He explores innovative treatments - from neurofeedback and meditation to sports, drama, and yoga - that offer new paths to recovery by activating the brain's natural neuroplasticity. Based on Dr. van der Kolk's own research and that of other leading specialists, The Body Keeps the Score exposes the tremendous power of our relationships both to hurt and to heal - and offers new hope for reclaiming lives. He worked with trauma more than 40 years [3].

According to V. Vernadsky, personality is the highest degree of human spiritual development, which is a stable set of socially important qualities that characterize the individual as a unique subjectivity, able to master and change the world. Every person is a man, but not every man is a person. People are born as individuals, and they become individuals. The concept of "personality" has three components: The physical component of personality; social component of personality; spiritual component of personality. These three main components of personality form a holistic system, and each of these components at different stages of human life can become dominant. Scientists distinguish four levels of rehabilitation: Emergency psychological care consists of primary care, screening and, if necessary, crisis intervention. The first rehabilitation level includes psychodiagnostics, assistance in adaptation and re-adaptation of combatants to new conditions in postwar society and psycho-social support. The second rehabilitation level consists of psychodiagnostics, psychological counseling and psychological support. The third level of rehabilitation is psychodiagnostics and individual psychotherapy, group psychotherapy or family psychotherapy. The last fourth level of rehabilitation is medical and psychological care.

Research results. As a result of theoretical analysis, it was revealed that in modern psychotherapeutic practice there are such types of psychological assistance as: psychodynamic psychotherapy; cognitive therapy; client-centered therapy by K. Rogers; dolphin therapy; behavioral therapy; positive psychotherapy; gestalt therapy; group psychotherapy; family post-traumatic therapy; body-oriented therapy; art therapy [1].

Psychodynamics is the movement, development, growth and attenuation, interaction and struggle of forces within the human psyche. K. Jung, A. Adler, O. Rank, R. Sullivan, K. Horney, E. Fromm and many other well-known scientists worked in the psychodynamic approach. If we recall history, the first references to the psychodynamic approach appeared in S. Freud in 1915. It all started with psychoanalysis, with the initial dynamic understanding of mental phenomena "... as manifestations of the struggle of psychic forces, as an expression of purposeful tendencies that work accordingly with each other or against each other"... S. Freud was the first to write in his work "Introduction to psychoanalysis "Our understanding of the psychodynamic approach:" We want not just to describe and classify phenomena, but seek to understand them as a manifestation of the struggle of psychic forces, as an expression of purposeful tendencies that work respectively with each other or against each other. We adhere to a dynamic understanding of mental phenomena" [15].

Psychodynamic therapy uses a psychoanalytic understanding of the functioning of the human psyche; both treatments try to change behavior therapeutically through psychological methods such as confrontation, clarification and interpretation; both require introspection on the part of the patient and empathic understanding on the part of the therapist; both pay close attention to countertransference. But psychodynamic forms of psychotherapy often emphasize the features of the patient's real life and minimize consideration of aspects of the relationship "therapist-patient". Psychodynamic therapy is understood as various forms of therapy based on the basic tenets of psychoanalytic teaching and accordingly focus on the influence of past negative experiences, which consists of trauma, emotions, fantasies, actions, the formation of a certain behavior that has become repetitive and thus affects on the actual physical, social and mental well-being of man. Psychodynamic psychotherapy creates a space for the patient in which he begins to "understand" his difficulties. Gradually, the patient better understands the characteristics of his own personality.

Cognitive-behavioral therapy (CBT) is quite effective in dealing with mental disorders. This method has been included in the treatment protocols of most mental disorders and is effective in the treatment of depression, eating disorders, anxiety disorders, post-traumatic stress disorder, personality 
disorders. It is used at different ages, in individual, group and family formats. Based on comparisons and studies of the effectiveness of therapy, NICE since 2004 considers CBT effective for various psychological problems.

Rogers' client-centered therapy in working with the client and the psychotherapist is based on the principle of "man-man". The personality of the therapist is very important. This position of Rogers is shared by many domestic scientists. According to M.I. Buyanov, the effect of psychotherapy depends not only on proper treatment, but also on the personal qualities of the doctor and the patient and their successful combination. The immediate feeling of sympathy or antipathy often plays a decisive role as a result of the interaction between the client and the therapist. Rogers' client-centered therapy solves the problems with which clients come to therapy well enough. Namely: professional problems, problems in marital relations, psychosomatic disorders. Thus, the main attention in the client-centered approach is focused not on the person's problems, but on the person himself, on his self.

Research on dolphin therapy began in the 50s - 60s of last century. In Ukraine, dolphin therapy began to be studied in the 1980s at the State Oceanarium in Sevastopol under the direction of L.N. Lukina. Dolphin therapy is a non-specific method of strengthening the body's defenses by psychosomatic and somatopsychic rehabilitation, psychosocial rehabilitation of patients. The uniqueness of the method is that dolphins have developed cognitive abilities, curiosity, friendliness and are easy to learn. They communicate through a variety of sounds, covering an unusually wide range of frequencies, from infrasound to sound and ultrasound. These signals can be pulsed or continuous. Pulse signals accompany echolocation, and continuous signals have a complex spectral composition that affects the skull and soft tissues of the head, which concentrate sound vibrations and act as an acoustic searchlight and sound lens. It has been proven that the ability of dolphins to emit ultrasonic waves is an important component in the healing process. Communicating with an exotic, cheerful animal carries an element of shock, stress with a positive result which has a therapeutic effect and helps to neutralize negative traumatic material. Research on the brain and psyche of dolphins today is very intensive in various countries around the world. The use of dolphin therapy for the rehabilitation of combatants today is a rather unique method in Ukraine. However, it is considered the most effective in the United States, so it is often used to restore the physical and psychological health of people who have experienced traumatic experiences. The analysis of the authors' scientific observations based on the results of dolphin therapy and the assessments of doctors, trainers and psychotherapists who rehabilitated patients shows that positive changes in emotional state occurred in $76 \%$ of patients. Improvement of speech and other forms of communication occurred in $41 \%$ of cases, ordering behavior in $45 \%$ of patients. Thus, this method is quite effective in working with a wide range of psychoneurological diseases in patients of different ages, taking into account the interests of both patients and animals. The largest dolphin therapy centers are in the United States, Russia, Turkey, Israel and Spain. In 2005, the only international program DAT (Dolphin Assisted Therapy) was developed, which is still used in the treatment of diseases such as: cerebral palsy; CNS disorders; speech and hearing disorders; Down syndrome and other complex genetic pathologies; neurosensory hearing loss; brain dysfunction; depression and mood swings; neurosis and other nervous disorders; disorders of memory and ability to learn; chronic diseases of the cardiovascular system and musculoskeletal system and others [9].

Behavioral therapy or behavioral therapy - was once based on the theory of learning, as well as on the principles of classical and operant conditioning. At the heart of this psychotherapy is the idea that the symptoms of some mental disorders appear as a result of incorrectly formed skills and habits. The main purpose of behavioral psychotherapy is to eliminate unwanted behaviors and develop useful behavioral skills for the patient. This psychotherapy is most successfully used to treat a variety of phobias, behavioral disorders and addictions. It is successfully used in working with those patients in whose condition it is possible to identify a specific symptom as a "target" for therapeutic intervention. The scientific and theoretical basis of behavioral psychotherapy is behaviorism. Behavioral therapy can be used alone or in combination with cognitive and other psychotherapies. Behavioral psychotherapy is a directive and structured form of psychotherapy. Its stages are the analysis of behavior, determination of the stages necessary for correction of behavior, gradual training of new skills of behavior, working off of new skills of behavior in real life. The main goal of behavioral therapy is to purposefully change the patient's behavior. Rapid improvement can occur even with disorders that have lasted for many years, such as long-term alcohol dependence, eating disorders, phobias. 
Positive psychotherapy describes that all illnesses, conflicts, stresses, or life problems of the patient are a given of life and this must be recognized. According to this psychotherapy, each person is endowed with abilities, thanks to which he is able to find solutions to the most difficult problems and implement them in his life. The authors of the theory say: "If there is a problem - then there is a solution." It orients the concentration on a holistic vision of life to the so-called holistic approach and orients the patient to an optimistic perception of its nature, taking into account all its real components. The main components of the method of positive psychotherapy are: Positum-approach, based on the principle of hope in relation to the constructive nature of man, his abilities and opportunities to solve their own problems; Psychodynamic differential analysis of the content of conflicts, based on the principle of harmonization of actual and basic abilities "Know" and "Love"; A 5-step strategy of psychotherapeutic care based on the principle of counseling, in the process of which clients learn to help themselves. Positive psychotherapy is a resource-focused method that systematically combines psychodynamic, cognitive and behavioral elements.

F. Pearls began Gestalt therapy in 1942. This approach is based on the following provisions: Man - is a holistic socio-biological being. Man and the environment is a single gestalt, which is called the field "organism and environment." Human behavior is subject to the principle of formation and destruction of gestalts. A healthy human body functions on the basis of its self-regulation. An urgent need arises and begins to occupy the dominant attention of the organism - the figure appears from the background. Convergence with the object and its adequate interaction with it leads to the satisfaction of the need - in this case, the gestalt is completed and destroyed. Contact is the basic concept of Gestalt therapy. All basic human needs can be met only in contact with the outside world. The place where the body meets the world around, in Gestalt therapy is called the boundary of contact. In this case, the degree of effectiveness of the implementation of its needs depends on how flexibly it can regulate its contact boundaries. Awareness - awareness of what is happening inside the body and in its environment. The main goal of Gestalt therapy is to increase awareness. This psychotherapy does not aim to change human behavior, and behavior changes as awareness develops. Everything relevant to the body is always happening at the moment.

Group psychotherapy is a combination and use of various psychotherapeutic techniques in the treatment of a group of patients. Almost all psychotherapeutic areas can be used in group therapy. Effective in inpatient and outpatient settings for the treatment of patients with neurosis, psychosis, behavioral disorders. Group psychotherapy became widespread due to: the desire to include more patients in psychotherapy; the belief that the best therapeutic effect can be achieved due to group interactions; recognition of the influence of socio-dynamic factors on human behavior. However, group psychotherapy does not replace individual: patients can participate simultaneously in both forms, often with different psychotherapists. Group psychotherapy is quite effective in working with patients who are unsure whether they will be able to communicate with others, for delinquent and paranoid people who are more likely to trust the same people as them than the psychotherapist. The advantage of the group approach is that the patient can communicate with different people. Each of them can be identified, and emotions and hopes, which are the essence of the patient's conflict, can be unconsciously transferred.

Systemic family therapy - as an approach developed along with cybernetics, and this is its significant difference from other psychotherapeutic approaches. This form of therapy and its effectiveness are scientifically recognized in Germany. In Austria and Switzerland, recognition took place in the 1990s. The person in this approach is not the object of influence and the client. The client is the whole family, the whole family system, it is the object of psychotherapy. At present, the theory is strongly influenced by the biological theory of systems by Chilean scientists Maturan and Varel, which was then expanded and strengthened by the sociological theory of systems by Nicolas Luhmann. It is necessary to tell the relatives of servicemen about the clinical signs of post-traumatic stress disorder, about their experiences and feelings, about the principles of behavior of relatives in this situation. It is important to inform them about the duration of the disease and the possibility of "flasbacks" effect. It is also necessary to conduct psychotherapeutic sessions with close relatives, because very often the behavior of a serviceman can contribute to the development of borderline mental disorders. In conversations with family members, we can recommend the following: try to help in order to psychologically return to a normal, normal life; listen carefully and with interest to the 
serviceman's story about what he had to go through. It is very important to let this person speak out, especially with the moral support of a loved one [5].

Body-oriented psychotherapy is focused on the study of the body, the client's awareness of bodily sensations to study what needs, desires and feelings are manifested in different bodily states and to teach realistic ways to solve problems in this area. The most well-known and basic type of body-oriented psychotherapy is Lowen's bioenergetic analysis. In addition, body-oriented psychotherapy is associated with Alexander's method, Rolf's structural integration, and Janow's primary therapy. All of them are based on the works of the famous psychoanalyst Wilhelm Reich, whose method is called "characterological analysis". Reich believed that the mechanisms of psychological protection and related protective behavior contribute to the formation of "muscle armor", which is expressed in the tension of different muscle groups, limited breathing and so on. It is possible to resist psychological protective mechanisms by change of a physical condition and influence on a tense area. Reich developed techniques for reducing chronic tension in each muscle group, when physical actions release veiled emotions and feelings. Breathing exercises are classic elements of body-oriented psychotherapy. These include shortness of breath, relaxation, or full breathing, which helps to relieve restrained feelings. In body-oriented psychotherapy, the emphasis is on acquaintance with the body, which implies the expansion of the sphere of awareness of the individual of deep bodily sensations.

Art therapy is a branch of psychology that helps the client to realize their inner state by creating a visual image, metaphors, symbols or art-therapeutic product. It simultaneously solves diagnostic and therapeutic problems. The use of different types of paints, colored pencils, chalk, alternative materials, dough, plasticine, sand, kinetic sand, quartz colored sand, and other natural materials - provide ample opportunities for the therapeutic process. Art therapy is literally an art treatment. Methods of art therapy help on a subconscious level to identify, realize, bring out the problem from the subconscious, to translate it into the field of consciousness, into the physical world, to materialize on paper or sand. Then, with the help of a specialist, you can work with this problem, expressed in the material world, by special methods and find ways to solve this problem.

Scientists distinguish three main psycho-therapeutic areas: psychoanalytic; behaviorist; humanistic. The WHO provides the following classification of methods for the selection of psychotherapy depending on the disease: 1 . In acute hysterical symptoms, the predominant suggestion; 2. At vegetative disturbances - autogenic training; 3. At life difficulties - "conversational" therapy; 4. At complex frustration with existence of a previous inclination - deep psychological methods; 5 . At phobias - behavioral therapy; 6. At frustration connected with family problems - family psychotherapy; 7. At characterological disturbances - gestalt therapy or psychodrama [14].

The major tasks of investigation: Restoration of the patient's household capabilities, that is, the ability to move, self-service and perform simple homework; Restoration of working capacity, that is, professional skills lost by a disabled person through the use and development of the functional capabilities of the motor apparatus; Prevention of the development of pathological processes leading to temporary or permanent disability, that is, the implementation of secondary prevention measures.

Rehabilitation process consists of such rehabilitation periods as: convalescence, readaptation and resocialization. Convalescence is a process of recovery with the restoration of impaired biological and psychological functions. During this period, pathogenetic therapy, surgery, and medical rehabilitation of patients are actively used. Readaptation - is the process of adaptation of the patient to life, work or study and the environment. At this time it is necessary to apply medical rehabilitation, social and vocational rehabilitation, as well as pathogenetic therapy. Resocialization is a process of rehabilitation through which a mature person restores previously broken ties or strengthens the old ones. Rehabilitation potential is a set of biological, psychophysiological characteristics and socioenvironmental factors that allow to realize the potential of the patient. It includes a systemic biopsychosocial characteristics of the human condition. The content of this characteristic can indicate what opportunities - objective and subjective can determine the change of the specified status [8].

Scientists identify such components of rehabilitation potential as: clinical and functional component, psychological component, occupational component, educational component and social component. There are such types of pathological personal reactions to the disease as: phobic reaction; depressive or anxiety-depressive reaction; hypochondriac or depressive-hypochondriac reaction; hysterical reaction and anosognostic reaction. A personal reaction can be qualified as adequate if: First 
- the patient's behavior, his experiences and perceptions of the disease correspond to the information received from the doctor about the severity of the disease and treatment, as well as their possible consequences; Secondly - the patient follows the regime, follows the doctor's instructions; Third - the patient is able to control their emotions. As a result of prolonged exposure to the stressor to which the body has adapted, a person gradually depletes the reserves of adaptive energy, and this leads to mental strain, which is the trigger for the development of various mental or somatic diseases. Under the influence of stress there are pronounced changes in the work of almost all body systems - nervous, endocrine, immune, hematopoietic and circulatory systems, digestive system and others. Clinical signs of mental disorders are varied [6].

With the help of classification and by selecting groups of patients with clinically similar psychopathological signs, doctors and psychotherapists try to ensure the planning of appropriate treatment, forecasting the course of the disease, in particular in the final stages. These features are the basis for the creation of ICD-11. The reaction of the individual and the support of this reaction are influenced by: the nature of the diagnosis; change in physical integrity and appearance; change of position in the family, society; life restrictions, deprivations associated with the disease; need for treatment and surgery [14].

Scientists from the World Health Organisation (WHO) distinguish three types of rehabilitation: Medical rehabilitation. It includes such drugs as: drug therapy, new and cosmetic surgery, physiotherapy and exercise therapy, psychotherapy, diet therapy, additional methods; Vocational rehabilitation, independent occupational therapy, vocational training or retraining and career guidance; Social rehabilitation consists of such an understanding as domestic and labor law, sociotherapy, socio-economic, socio-hygienic and legal counseling [2].

There are eight levels of rehabilitation potential: biomedical potential; psychophysiological potential; personal potential; educational potential; social and domestic potential; professional or labor potential; social potential; and socio-environmental potential. It is established that rehabilitation is carried out in various institutions, namely crisis centers, early social rehabilitation centers, social and psychological rehabilitation centers, specialized rehabilitation centers, military hospitals, shelters, medical and specialized institutions where a multi-disciplinary team of specialists works. The effectiveness of rehabilitation is assessed on the basis of full provision of the full range of rehabilitation measures: medical, social, psychological, pedagogical, professional. Among the disorders that cause the need for rehabilitation, scientists include: disability, alcoholism, drug addiction, loss of social status, work, housing, loved ones, crime.

Conclusions. After analyzing the above, we can identify 3 degrees of rehabilitation potential for resocialization: The high potential of rehabilitation is determined when the implementation of all aspects of rehabilitation is forecasted - psychological, functional, family and social recovery, social. Also at partial restoration of function full social, psychological and family-social recovery of the combatant is reached. The average rehabilitation potential of a combatant is determined if it is predicted that moderate or mild dysfunction will persist with incomplete social recovery at the time of realization of the professional role, but with the possibility of his full social and domestic activity. The low potential of rehabilitation of the companion is determined if the preservation of a pronounced functional defect is predicted, which is accompanied by violations of the psychological and familysocial direction of recovery.

Dolphin therapy is an effective method of working with a wide range of psychoneurological diseases in patients of all ages, taking into account the interests of communities as such people and animals. [9] Therefore, we consider it appropriate to invite this method in the rehabilitation of combatants. After analyzing the existing methods, we came to the conclusion that effectively affects the work with combatants, can be mental psychotherapy and combining it with a behavioral method.

We consider it important to draw the attention of scientists and practitioners to the analysis of the rehabilitation potential and finding an effective combination of approaches and methods in the provision of psychological assistance and rehabilitation measures with combatants who have undergone the remote consequences of stressful influences. In our opinion, the use of both independent types of psychological assistance and their complex combination will contribute to the neutralization of traumatic material, complete processing, further elimination of the long-term consequences of stressful influences in combatants, their adaptation to social life and the restoration of mental health. Analyzing the above, we see that the current state of our society is associated with a 
complex of various factors of political, economic, demographic and spiritual nature. All this has a very negative effect on people, and as a result, quite often our citizens cannot cope alone with the problems in which they find themselves for objective or subjective reasons. Summing up, we came to the conclusion that Ukrainian society needs qualified rehabilitation activities of highly qualified specialists, which are carried out in special rehabilitation centers.

\section{REFERENCES}

1. Agayev N.A., Kokun O.M., I.O.Pishko I.O. (2016) Zbirnyk metodyk dlia diahnostyky nehatyvnykh psykhichnykh staniv viiskovosluzhbovtsiv. [Collection of methods for diagnosing negative mental states of servicemen]. Kyiv: Metodychnyi posibnyk [in Ukrainian].

2. Babova K.D., Pinchuk I. Y., Steblyuk V.V. (2003) Reabilitatsiia postrazhdalykh v umovakh nadzvychainykh sytuatsii ta boiovykh dii. [Posttravmatychnyi stresovyi rozlad.Rehabilitation of victims in emergencies and hostilities. Post-traumatic stress disorder]. Odessa [in Ukrainian].

3. Bessel van der Kolk (2015) The Body Keeps the Score: Brain, Mind, and Body in the Healing of Trauma. London [in English].

4. Voronova V.I., Shevchenko V.E., Korshevnyuk D.O., Baibayev D.S., Kravchenko B.V., Galkin S.A., Malko I.V. (2003) Psykholohichne suprovodzhennia viiskovosluzhbovtsiv v diialnosti za ekstremalnykh umov. Natsionalnyi universytet fizychnoho vykhovannia i sportu Ukrainy. [Psychological support of servicemen in extreme activities conditions. National University of Physical Education and Sport of Ukraine]. Kyiv: metodychni rekomendatsii [in Ukrainian].

5. Kine Terence M., Friedman Matthew J. (2005) Эffektyvnaia terapyia posttravmatycheskoho stressovoho rasstroistva. [Effective therapy of post-traumatic stress disorder]. Ed. Foa E. B. Moscow "Kogito-Center" [in Russian].

6. Zeigarnik B.V. (1998) Psykholohyia lychnosty: norma y patolohyia. [Psychology of personality: norm and pathology]. Voronezh [in Russian].

7. Korobov M.V., Shelomanova T.N. (2000) Orhanyzatsyia professyonalnoi podhotovky spetsyalystov po reabylytatsyy $\mathrm{v}$ uchrezhdenyiakh hosudarstvennoi sluzhbi medyko-sotsyalnoi эkspertyzy. [Organization of professional training of rehabilitation specialists in institutions of the state service of medical and social examination]. Moscow: Problemi reabylytatsyy [in Russian].

8. Sait Ministerstva okhorony zdorovia. Nakaz "Pro zatverdzhennia Instruktsii pro vstanovlennia hrup invalidnosti. [Ministry of Health, Order . On approval of the Instruction on the establishment of disability groups]. Kyiv Retrieved from URL: https://ips.ligazakon.net/document/TM021568_[in Ukrainian].

9. Ministerstvo okhorony zdorovia. (2010) Informatsiinyi lyst pro provedennia delfinoterapii u ditei ta pidlitkiv. [Ministry of Health - Information letter on dolphin therapy for children and adolescents]. Kyiv [in Ukrainian].

10. Kabinet Ministriv Ukrainy. (2007) Pro zatverdzhennia Polozhennia pro indyvidualnu prohramu reabilitatsii invalidiv. [On approval of the Regulations on the individual rehabilitation program for the disabled. Resolution of the Cabinet of Ministers of Ukraine]. Official Gazette of Ukraine. Kyiv [in Ukrainian].

11. Sait Verkhovnoi Rady Ukrainy. (2015) Pro zatverdzhennia Polozhennia pro psykholohichnu reabilitatsiiu viiskovosluzhbovtsiv Zbroinykh Syl Ukrainy, yaki braly uchast $\mathrm{v}$ antyterorystychnii operatsii, pid chas vidnovlennia boiezdatnosti viiskovykh chastyn. [On approval of the Regulation on psychological rehabilitation of servicemen of the Armed Forces of Ukraine who took part in the anti-terrorist operation during the restoration of military units] Order of the Ministry of Defense of Ukraine dated Official site of the Verkhovna Rada of Ukraine. URL: http://zakon3.rada.gov.ua/laws/show/z0237-16/card2\#Card_Kyiv [in Ukrainian].

12. Protopopov V.P. (1961) Tsel y zadachy, vypolnenye kotorykh ya posviatyl svoiu zhyzn. [The purpose and tasks, the implementation of which I dedicated my life]. URSR: Yzbrannye Trudy [in Russian].

13. Ministerstvo okhorony zdorovia. (2011) Reabilitatsiinyi potentsial. Nakaz Pro zatverdzhennia Instruktsii pro vstanovlennia hrup invalidnosti. [Rehabilitation potential. Ministry of Health, Order "On approval of the Instruction on the establishment of disability groups] Regime of access to the resource URL: http://search.ligazakon.ua/l_doc2.nsf/link1/TM043108.html__Kyiv [in Ukrainian].

14. Sokruta V.M. (2019) Fizychna, reabilitatsiina ta sportyvna medytsyna. [Physical, rehabilitation and sports medicine]. Kramatorsk: Pidruchnyk dlia studentiv i likariv. Kashtan [in Ukrainian].

15. Freud Z. (2007) Vvedenye v psykhoanalyz. [Introduction to psychoanalysis]. Moscow: ZBERIGACH [in Russian]. 